\title{
HOW CAN A CLUSTER POLICY ENHANCE ENTREPRENEURSHIP? \\ EVIDENCE FROM THE GERMAN “BIOREGIO” CASE
}

\author{
Claire Champenois \\ Audencia Nantes School of Management \\ cchampenois@audencia.com \\ Article published in Environment and Planning C: Government and Policy, \\ volume 30, pp. 796-815 (2012)
}

\begin{abstract}
:
This paper investigates the mechanisms through which a cluster policy can enhance entrepreneurship defined as new venture creations. It is based on the sudy of a cluster policy ("BioRegio") that strongly stimulated new firm creations in biotechnology in Germany after 1996. The process induced by BioRegio at the territory-level is analyzed over a 10 year period (1995-2004). The article identifies a three-step social mechanism through which a cluster policy can enhance entrepreneurship. The presented results strengthen the literature on cluster policies and clusters on the specific issue of entrepreneurship: four main contributions are suggested.
\end{abstract}

\section{Keywords:}

academic entrepreneurs, BioRegio, biotechnology, regional innovation systems, institutional theory 


\section{Introduction}

Many Western governments have recently implemented public policies directly targeted at developing clusters, defined as "geographic concentrations of interconnected companies and institutions in a particular field" (Porter, 1998, p.78). In high-technology sectors, such "cluster policies" generally aim at increasing the concentration of firms and interorganizational networks between small and medium enterprises, large firms, research centres/universities and public authorities in a given technological area and territory ${ }^{1}$ (Borràs and Tsagdis, 2008; Burfitt et al., 2007; Duranton et al., 2009). In Finland for example, cluster-based policies have even become the general form of national innovation policy (Author's name, in this special issue), while in Germany, the BioRegio program was one of the first cluster-based national technology policies implemented by European states to enhance innovation and economic competitiveness (Dohse, 2007).

In high-tech sectors, the dynamic of clusters mostly relies on new venture creations that commercially exploit the latest scientific and technological discoveries (Casper, 2007; Powell et al., 2011; Saxenian, 1994). The literature dedicated to high-tech clusters and entrepreneurship in Western contexts has identified several factors enabling entrepreneurship, such as the type of networks developed by entrepreneurs (Grossetti and Barthe, 2008; Maurer and Ebers, 2006; Powell et al., 2011), the "localized knowledge spillovers" between research institutes and new ventures (Audretsch and Stephan, 1996; Feldman, 2003; Zucker et al., 1998), or the availability of specific local collective competition goods, called "start-up goods", (e.g. technology transfer services, "seedcorn" and follow-on equity) (Proudfoot, 2004). Yet, in all of these contributions, cluster policies were not considered as one of the factors possibly fostering entrepreneurship, although Feldman et al. (2005) invite

\footnotetext{
${ }^{1}$ For the OECD, cluster policies comprise " the set of policy activities that aim to stimulate and support the emergence of these networks, strengthen the inter-linkages between the different part of the networks; and increase the value added of their actions" (OECD, 1999).
} 
consideration of public policies as shaping the economic success of entrepreneurs building firms in clusters.

The objective of this article is to address the important question of "how or through which mechanisms can a cluster policy enhance entrepreneurship?". Entrepreneurship is defined as the creation of new ventures (Ireland et al., 2005). In a Schumpeterian perspective, entrepreneurs are viewed as innovators combining in idiosyncratic ways heterogeneous production factors (e.g. capital, workforce, technological knowledge) and, by so doing, creating a new product, a new production method, a new market or a new supply chain (Schumpeter, 1934).

This research question has hitherto been largely overlooked, as most existing contributions have focused not on the creation of new ventures per se but on the more general regional innovation dynamics (including, for example, inter-firm and firm-university cooperations, in addition to venture creations). Consequently, there is no theoretical contribution that offers a feasible answer to this issue and the best research strategy to address it is inductive theory building from case study (see Eisenhardt, 1989; Eisenhardt and Graebner, 2007). The case chosen is BioRegio, a cluster policy that strongly stimulated biotechnology entrepreneurship in Germany. The process induced by this policy is analyzed over a 10 year period (19952004) in two regions.

The structure is as follows. In the first section, I present the theoretical background. Then, the research methodology and the empirical data are described, before an overview of the BioRegio program is given. The following section summarizes the empirical results, accounting for the processes initiated by BioRegio in both regions studied. In the final section, a theoretical proposition on how a cluster policy can enhance entrepreneurship is outlined. It 
is also argued that the results extend existing approaches to cluster policies on the specific issue of entrepreneurship.

\section{Theoretical background}

Two main approaches have been used to analyze cluster policies. They addressed the issue of their effect on new venture creations only obliquely.

First, the "regional innovation systems" approach (Braczyk et al., 1998; Cooke et al., 1997) has focused on the innovation capacity of regions in general - with new venture creations being only one part of this. It has previously been identified that a culture among regional actors of cooperation and trust was a condition for increasing the likelihood of having a strong potential for regional innovation systems, that is, systems of collective order characterized by regular interactions between regional actors and linkages between region-based organizations (Cooke, 1998, 2001; Cooke et al., 1997). In this perspective, regional institutions are considered a key factor explaining the regions' success or failure in innovation (Doloreux and Bitard, 2005).

Consistent with the regional innovation systems approach, relatively few contributions have identified that a BioRegio-type cluster policy could significantly enhance communication and cooperation among regional key actors (Dohse, 2000b) and moreover "generate relatively strong mobilization effects for innovative activity by stimulating the division of innovative labor" as well as "induce actors to establish new contacts, deepen existing relationships and create new innovation networks that have not existed yet" (Eickelpasch and Fritsch, 2005, p. 1276). However, little is known about the causality link - which is hypothesized in these contributions - between these new cooperative interactions at the territory-level and the observable increase in venture creations. In addition, the concept of "regional institutions" often has limited explanatory power regarding the general innovation dynamics taking place 
within territories and, specifically, high-tech firm creations, as it may designate very different empirical realities (either formal institutions or informal ones, regional organizations, the region itself or, sometimes, a process of "institutional learning") (Doloreux and Bitard, 2005). The second approach used to study cluster policies comes from institutionalism, especially following the "varieties of capitalism" tradition (Hall and Soskice, 2001). This body of research has viewed national cluster policies as aiming at overcoming obstacles to innovation that result from the institutional framework of a given nation. In Germany, cluster policies like BioRegio seek to overcome hurdles such as the bank-based financial system, the regulative nature of German institutions, which, combined with non-market patterns of coordination, create constraints against firms developing radically innovative products (Casper, 2000; Sternberg et al., 2010). BioRegio was aimed at overcoming specific institutional barriers: the low interest of pharmaceutical/chemical companies, weak impulses from academic research to found new firms, limited government support, and an institutional context not aligned with the needs of biotechnology (e.g. no venture-capital market) (Krauss and Stahlecker, 2001). In this perspective, BioRegio enabled the appearance of radically innovative ventures that are traditionally not stimulated by the German national innovation system, because it induced an adaptation of the institutional framework in which firms are embedded, by creating sector-specific institutions supporting entrepreneurs (such as biotechnology promotion offices, technology parks and incubators) (Casper, 2000) and because it improved the venture-capital offer for biotechnology firms within territories (Krauss and Stahlecker, 2001). Compared to the US, German cluster-based technology policies present one specificity: on top of regional states and municipalities, the Federal government intervenes in them, using them as "top-down stimuli to mobilize regional efforts" (Sternberg et al., 2010, p. 1077). Nonetheless, a few questions remain: how does this mobilization take place and who are the key regional actors involved? What is the role played 
by the Federal state? The formal existence of specific institutions does not suffice to understand the development of entrepreneurship: the action of these institutions as well as their utility for entrepreneurs should be empirically investigated.

In order to understand how a cluster policy can enhance entrepreneurship, the complex and dynamic social process of emergence and stabilization of regional interactions and new institutions supporting entrepreneurs should all be studied, as well as the use of these sectorspecific support institutions by entrepreneurs.

\section{Methodology and empirical data}

In order to address the issues raised, the adopted research strategy is inductive theory building from case study - rather than theory testing - that is "a research strategy that involves using one or more cases to create theoretical constructs, propositions and/or midrange theory from case-based empirical evidence (...), [t] he central notion [being] to use cases as the basis from which to develop theory inductively" (Eisenhardt and Graebner, 2007, p. 25).

The research design is a longitudinal "collective case study" (Langley and Royer, 2006) or an "embedded case study" (Yin, 1994), that is, a single case study of a national cluster policy's implementation including two sub-units of analysis: regions and firms. Two regions applying to BioRegio were studied (the Rhine-Neckar Triangle around Heidelberg and BerlinBrandenburg) as well as 41 biotechnology firms, 22 of which could be analyzed more intensively in a longitudinal fashion. The sub-unit sample was built following two methodological principles: replication logic and contrasting cases. The replication logic is central to building theory from case studies (Eisenhardt, 1989): like a series of related laboratory experiments, multiple sub-unit cases are discrete experiments that serve as replications to the emerging theoretical propositions (Yin, 1994). Therefore, the theoretical propositions that are offered on how a cluster policy can enhance entrepreneurship rely on the 
fact that similar BioRegio implementation processes were observed in the two regions studied, and that similarities in the use of local support actors among heterogeneous biotech firms were identified. For replication purposes, the most appropriate research strategy is to sample constrasted cases (Eisenhardt, 1989). This explains why two regions were selected in that they were entrepreneurially rich and did apply to BioRegio, albeit with contrasting outcomes (the Rhine-Neckar Triangle being chosen as a model region by the Federal Ministry of Research, unlike Berlin-Brandenburg). Both regions belong to the largest and most successful German life sciences clusters (Development Bank of Japan, 2006) ${ }^{2}$. Criteria for choosing the RhineNeckar-Triangle as a winning region case were: (i) privileged access to the research field (Yin, 1994), because of personal contacts and geographic proximity, (ii) the fact that, at the time of the fieldwork, the Munich case had been more documented in the academic and practitioner's literature than the Rhine-Neckar Triangle, (iii) the existence of an ambitious state policy fostering biotechnology in Bavaria prior to BioRegio, which could have made it difficulty to differentiate the mechanisms enhancing entrepreneurship that were due to BioRegio from those due to this older state policy. The main sampling criteria for firms was to maximize the heterogeneity of the cases (e.g. different technologies and markets, types of funding, profiles of founders). Firms that did not receive BioRegio funding in the RhineNeckar Triangle were included in the sample.

Data were collected between January 2002 and September 2004. Semi-directed interviews were conducted with 157 representatives from the German biotechnology industry (see appendix). Numerous and highly knowledgeable informants were used who offer different views on the effect of BioRegio. This can help limit biases (Eisenhardt and Graebner, 2007).

\footnotetext{
${ }^{2}$ The Rhine-NeckarTriangle gathers several internationally recognized research centres in life sciences as well as major pharmaceutical/chemical companies (e.g. Merck, Roche Diagnostics, Sanofi-Synthelabo, BASF/Abbott). In 2005, 46 biotech firms with 1410 employees were registered. Berlin-Brandenburg has 28 universities and higher education institutions and enjoys the highest density in Germany in terms of research capacities. Schering is the only large pharmaceutical company located in the region. In 2005, 156 biotech ventures and 3200 employees were in Berlin-Brandenburg. (Sources: author's data; Development Bank of Japan, 2006).
} 
To avoid the possibility of memory recall bias, interview data were supplemented with archival data - including, for example, written application forms to BioRegio given to the Federal Ministry of Research in 1996 by local actors and confidential activity reports by BioRegio-derived support institutions.

The results and subsequent propositions generated in this article result from a rigorous data analysis process. Interview and written data were systematically analyzed and compared along major emerging themes (for example, the collective mobilization initated by BioRegio). Statements drawn from this comparison were summarized in two detailed intermediary casestudy write-ups for each region of about 100 pages each. As advocated by Yin (1994), when the analytic strategy is explanation building from a case study, the data analysis process was iterative: the statements made in each regional write-up were compared against each other, often leading to revised statements. Statements or propositions were only made when several different data sources supported them. The ensuing research propositions are not universal, but historically situated mid-range theories ${ }^{3}$.

\section{Presentation of the BioRegio contest}

Launched in 1995 by the Federal Ministry of Education and Research (BMBF), BioRegio aimed at strengthening the German biotechnology industry - biotechnology being seen as a key technology and a driver of economic growth - and at catching up with the US and the UK in this sector. The program's objectives were to develop life science clusters, increase start-up creations, support the growth of existing firms, foster venture capital, and improve acceptance of biotechnology among the broader population. Playing a prototype role in Germany, this

\footnotetext{
${ }^{3}$ The fact that Berlin-Brandenburg has very rich scientific capacities in life sciences limits the generalization possibility of the results observed in this region to other 'losing' regions. It is likely that in less scientifically dense regions that were not selected by BioRegio the contest process did not provoke the emergence of so many innovative firms as it did in Berlin-Brandenburg.
} 
cluster policy was replicated by BMBF in policies supporting biotechnology ${ }^{4}$, in programs fostering other technological fields, such as multimedia or nanotechnology, as well as in policies promoting technological development elsewhere in Germany (Dohse, 2000a, 2007; Eickelpasch and Fritsch, 2005).

BioRegio is a cluster policy that strongly stimulated the creation of new ventures in the second half of the 1990's (see figure 1), pushing the German biotechnology industry to the top position in Europe by 2000.

Insert Figure 1 about here

The main actors involved in the field consider the BioRegio program as the founding event of this industry ${ }^{5}$. The evaluation of BioRegio commissioned in 2005 by the BMBF also concluded that BioRegio "significantly contributed to the creation/boom of a German biotech industry in the mid- and end 1990's and to the emergence of a commercial biotech sector in Germany" (Staehler et al., 2007, p.4). The involvement in BioRegio enabled BerlinBrandenburg, the Rhine-Neckar Triangle and Munich to become the leading biotechnology clusters in Germany (Development Bank of Japan, 2006). Interestingly, comparable entrepreneurship dynamics occurred in the 'winning' regions, or those territories selected by the Federal ministry as which occurred in the 'losing' ones during the public program (1997$2001)^{6}$

Specifially, the ministry asked regions to organize themselves in order to promote innovation (Eickelpasch and Fritsch, 2005) and to propose a local project by the end of 1996, which was

\footnotetext{
${ }^{4}$ e.g. BioChance launched in 1998, BioFuture in 1998, BioProfile in 1999, BioChance Plus in 2004, ExistGoBio in 2005.

5 Mainly focused on health care applications ("red biotechnologies"), the German biotechnology industry produces a pipeline of new pharmaceutical compounds: in 2007, 316 products were being developed by these companies (Ernst \& Young, 2008).

${ }^{6}$ BioRegio's evaluation report notes that firm creations were more numerous in winning regions than in the remaining regions (Staehler et al., 2007, p.28). Nevertheless, it should be highlighted that firm creations took place in all the 17 bioregions. This constitutes a counter-intuitive fact that will be explained later in the paper.
} 
supposed to meet the above mentioned general objectives of the ministry. Here "regions" were not to be interpreted in an administrative sense: the regional actors could freely define the geographical boundaries of their territories, which did not have to be consistent with the German administrative structures of regional states [Länder], circles [Kreise] and municipalities [Kommunen]. More precisely, the Federal ministry (BMBF) asked regional actors to (i) make an inventory of their capacities and competencies in biotechnology (size, number, profile, production of region-based research institutions, university hospitals and biotechnology firms; existing interactions between these organizations) and (ii) to propose a concept of "integration of capabilities and activities in biotechnology" at the regional level (Source: BioRegio call for projects). Thus, actors were asked to conceive a strategy and suggest tools to transform the regions' academic knowledge base into commercial products through firm creations, and knowledge transfer between science and industry. Regarding firm founding, local actors were asked to propose housing solutions for start-ups including incubators and technology parks, as well as funding schemes. Another explicit demand from the Federal state was that local actors should combine in their project already existing federal, regional and municipal public programs supporting biotechnology and new ventures.

Seventeen regions submitted "local concepts" and applied for BioRegio's funds in autumn 1996. In November 1996, three winners were announced by the ministry: Heidelberg ${ }^{7}$, Cologne, and Munich ${ }^{8}$. Over a five year period (1996-2001), each of these "model regions" gained access to a 25 million euros budget for collaborative R\&D projects carried out by small and medium-sized enterprises in their region. Jena, in the eastern part of Germany, received a special prize of 15 million euros.

\footnotetext{
${ }^{7}$ I will use Heidelberg and Rhine-Neckar Triangle in an undifferentiated way in the article.

${ }^{8}$ Criteria for selection reflected BMBF's demands to the regions. The ministry based its judgment mainly on the following elements: existing biotechnology companies in the region, number and profile of biotechnology research institutes, interdisciplinary research collaborations, supply of support services like patent offices or advice services, local strategy of new product- or service development based on scientific knowledge, systems to promote the coming or creation of biotechnology firms in the region, and funding possibilities for life sciences companies. These criteria were known by all applicants.
} 


\section{Empirical results}

This section presents key findings (partly summarized in table 5) describing the process initiated by BioRegio in two regions. It shows: (i) how regional contexts and institutions matter, as the dynamics taking place and the solutions conceived are region-specific; (ii) that similar trends can be identified in different regional settings; and (iii) that time plays a significant role in the dynamics and success or failure of this program. Three mechanisms through which the cluster policy studied enhanced entrepreneurship are successively presented (4.1 to 4.3), before pointing to their fragility (4.4).

\subsection{Genesis of a local collective action to support entrepreneurs (1995-1996)}

The launch of BioRegio gave impetus to a new territory-based collective action aimed at sustaining entrepreneurship, mostly enabled by convergent interests among regional actors. Once BioRegio was announced by the BMBF in October 1995, heterogeneous local actors mobilized around the application process and conceived localized projects, which were subsequently submitted to the BMBF in autumn 1996. The decision to participate in the public contest was made in contingent ways in both of the regions studied, that is, at different times, on the initiative of different actors, and motivated by singular reasons (see table 1).

\section{Insert Table 1 about here}

However, this decision generated in both Berlin and Heidelberg a generalized participation of various public and private actors. The initiators in both regions succeeded in convincing a range of local actors - mainly from research institutions, pharmaceutical and biotechnology firms, public local authorities (state ministries, technology parks supported by municipal and regional governments, chambers of commerce and industry), and finance institutions - to 
participate. Consequently, organized collective actions took place gathering these aforementioned actors with the goal of conceiving an application to BioRegio. Workgroups were created to prepare a specific part of the application file to be submitted to the $\mathrm{BMBF}^{9}$. The groups designed a local project consisting of existing as well as newly created organizations and tools. These were aimed at fostering technology transfer in biosciences, especially promoting firm creation activities. In Berlin-Brandenburg, they created BioTop, a "central coordination cell for all requests in biotechnology", which served as a "one-stop agency whose core mission [was] to create connections between the various activities taking

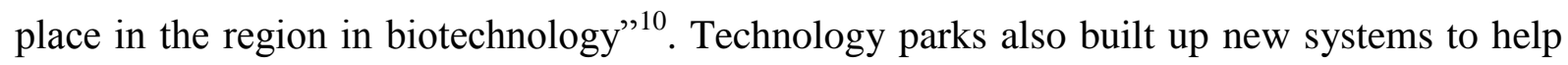
firm founders, like "Biostart", a sensibilization and teaching program aimed at making scientists aware of start-up creations and at teaching them basic business administration skills. In the Rhine-Neckar Triangle, local actors conceived a four-fold structure: a not-for-profit organization (called "BioRegio association") helping scientists wanting to create a company in the incubation phase of their project, which would then select and manage the access to the BMBF BioRegio grants; a seed financing fund for very early-stage companies; a company (later renamed "Heildelberg Innovation") which both managed the investment fund and assisted entrepreneurs in their firm creation activities; and a life sciences park hosting new ventures.

Every local actor had both singular and specific reasons for wanting to take part in BioRegio (see table 2), but these reasons converged in the same general direction.

Insert Table 2 about here

\footnotetext{
${ }^{9}$ For example, in Heidelberg, work was divided between four groups dedicated, respectively, to research, funding, preparation of the BioRegio file, and communication with the public.

${ }^{10}$ Quoted from Berlin-Brandenburg BioRegio application file, p. 76.
} 
Three characteristics of the BioRegio program facilitated the congruence of motivations. First, BioRegio was specific to a technological field that was surrounded in the second half of the 1990's with positive expectations shared among policy makers. Biotechnologies were identified as key technologies for future medical, agricultural, food and industry innovations and for national economic competitiveness (e.g. BMBF, 1996a, 1996b). These taken-forgranted assumptions of the benefits of biotechnologies created a cognitive framework shared by federal, regional and municipal policy makers as well as various institutional actors (e.g. chambers of commerce, saving banks). Concomitantly, they facilitated the convergence of interests of these actors towards participating in BioRegio.

Second, the objectives formulated by the ministry were in harmony with other research and innovation or local development policies that were being implemented at the same time. For example, universities were increasingly obliged by federal and regional governments to generate external revenues, as well as to conduct not only basic but also applied research. This meant they needed to be concerned with the economic use of the scientific knowledge produced. As part of territorial development policies since the 1980's, regional and municipal governments had also started to build "technology parks", which offered well-equipped laboratory and office spaces to entrepreneurs. While Heidelberg's technology park appeared in 1985 , decisions to build several science parks dedicated to biotechnology were made in Berlin and Brandenburg in the first half of the 1990's as part of a regional policy following the German reunification. Another major innovation policy implemented in 1994 was a very strong incentive program promoting venture-capital called "BTU” ("Equity investment for young technology ventures") by the Federal Ministry of Economy. This program provided cofinancing ("silent partnership") for young high-tech firms by a federal public financial institution called "Tbg” (Technology Investment Company). Here, the state, through the Tbg, offered one additional euro to any equity investor investing one euro in an innovative firm, up 
to a limit of 1,5 million Euros. In addition, a public bank called "KfW" (Credit institution For Reconstruction) offered to refinance $75 \%$ of the funds invested by an equity investor in a high tech venture: out of 10 euros invested in a start-up, a venture-capital firm received 7,5 Euros from the KfW. On top of these financial subsidies, both tools partly covered the bankruptcy risk borne by investors in firms benefiting from one of these programs.

The third characteristic of the BioRegio program that facilitated significant alignment of motivations was the large amount of freedom left to local actors to conceive their project: the geographical boundaries of their territory could be freely defined, as well as the various tools to be utilized.

\subsection{Formalization of the initial cooperation by organizational creation/stabilization} (1996-2001)

The second mechanism generated by BioRegio was a formalization of the initial cooperation through the creation, then ensuing stabilization of new organizational structures and tools to sustain biotechnology entrepreneurs.

\subsubsection{Genesis of local support organizations and tools (Nov. 1996-1997)}

In the months following the BioRegio's results (announced in November 1996), interconnected new organizations and tools intended to sustain biotechnology entrepreneurs at the territory level were developed in 'losing' regions as well as in 'winning' ones. During the application phase, as previously described, such tools and organizations had been conceived. Some of these were even implemented before the results of the contest were known, such as BioTop in Berlin. Others were implemented afterwards not only in Heidelberg, in conformity with what had been planned, but also - and surprisingly - in Berlin-Brandenburg (e.g. "Biostart"). The undifferentiated implementation of plans conceived within the contest phase 
can be explained by the emergence of opportunities regarding the fostering of entrepreneurial projects, which territorial actors decided to exploit in the following years.

The conception phase of a local project for BioRegio was characterized by repeated interactions between representatives from local research institutes, universities, support actors, Länder, cities, and financial institutions, which resulted in an increased degree of inter-knowledge among local actors.

"The BioRegio contest led people who didn't know each other and did not talk together to get to know what the others were doing. Even the various university research institutes did not talk to each other before BioRegio!" (BioRegio association, Heidelberg)

These increased interactions enabled the emergence of a collective territory-based action of identifying local problems and conceiving adhoc solutions in the form of tools and organizations, which both reflected and responded to constraints specific to their territories. For example, in the 'losing' region case (Berlin-Brandenburg), the team in charge of conceiving a project proposal for BioRegio had to address the following "problem": numerous $R \& D$ projects were proposed by scientists because of the high number of research institutions engaged in biotechnology within the region, but these projects were too often regarded as "academic". To resolve this, the local team structured the research activities by defining thematic axes in which R\&D projects could be integrated. They also searched for potential industry partners for purely academic projects. Finally, they also tried to convince local politicians and other representatives from both Länder, as well as local financial institutions, to set up a seed fund as in the Heidelberg case ${ }^{11}$. Consequently, at the time the BioRegio results were announced, various opportunities had already emerged, which local actors like BioTop sought to exploit. For instance, contacts had been established with local financial institutions which resulted in the establishment of a network of financial institutions interested

\footnotetext{
${ }^{11}$ However, the various attempts failed because of financial difficulties experienced by the Länder and internal conflicts between representatives from both political and administrative sections.
} 
in investing in biotechnology start-ups ("Biofinanz"). Thematic R\&D networks connecting academic and industrial partners were also created and managed by BioTop, increasing the likelihood of receiving funding from BMBF and the Länder.

Having explored the launch of BioRegio, we now turn to consider the additional dynamics that occurred in the years following the contest results.

\subsubsection{Stabilization of BioRegio-derived organizations (1998-2001)}

Many organizations created within the BioRegio process became enduring and viable entities. In the winning regions, funding was received from the Federal ministry as well as from industry and banks as planned in the application. In the 'losing' regions, they also managed to convince other institutions that they should exploit the opportunities that had emerged during the application phase. Therefore, they still obtained funding which guaranteed their survival. For example, at the end of 1997, the Berlin-based agency BioTop received funding for staff and equipment over a few years, from both Länder Berlin and Brandenburg and from the German Union for Chemical Industry.

\subsubsection{An intermediation role of local support organizations (1998- 2001)}

The third mechanism initiated by the cluster policy was that the new BioRegio-derived organizations began cooperating with an increasing number of other local organizations sustaining entrepreneurship. In turn, they were able to play an intermediation role between the entrepreneurs and relevant resource providers.

The context by the end of the 1990's was an emergence of new tools and organizations supporting entrepreneurs and these were implemented mainly by regional ministries and cities (see table 3). 
Insert Table 3 about here

Thus, the BioRegio-derived organizations cooperated with these newly created local support organizations because of an inter-knowledge process and a labor division among these complementary organizations. More precisely, these support organizations played an intermediation role between firm founders and their partners.

By playing a counseling role, they first provided entrepreneurs with valuable information that was important to implementing their project (e.g. how to proceed for incorporation, how to file a patent, what type of funding exists, and what documents to produce for financing partners).

"My job is to support entrepreneurs. Concretely, this means that when someone comes and tells me that he wants to create a company, he gets from me everything he needs to know. I tell him how to write a business plan, I give him a template, for example the Deutsche Bank CD-Rom or the business plan contest's guide. I explain to him also that he needs to see a lawyer to incorporate his company and that the lawyer will give him advice on the legal structure to choose (GmbH or AG)." (technology park Berlin)

More importantly, they also acted as contact-makers by putting (would-be) entrepreneurs into contact with the various partners that would bring resources required to implement their project: (i) scientific partners (mainly from local academic research institutes, in order to obtain public grants for $\mathrm{R} \& \mathrm{D}$ network projects), (ii) other supporting actors (technology parks, technology transfer offices, BioRegio local organizations), and, above all, (iii) financial actors for funding. The last arrangement differed slightly according to the region (see table 4).

Insert Table 4 about here

Finally, local public support actors encouraged certain types of behaviors, thereby playing a third role of norm diffusion. For example, as they put start-up founders in contact with 
venture-capital investors they presented the latter as natural and desirable partners for entrepreneurs.

Moreover, fieldwork on entrepreneurs' modalities of building up companies also shows that firm founders and Chief Executive Officers ("CEOs") quite frequently mobilized these local support organizations and tools to obtain needed resources, especially funding. In seven of the 12 in-depth longitudinal analyses of firms created between 1996 and 2000 carried out by the author, entrepreneurs mobilized (in addition to their interpersonal networks) external organizations, meeting devices newly established in their region, and impersonal information tools to create contact with financing actors.

Consequently, local support actors and tools catalyzed the emergence of new venture projects and helped entrepreneurs combine various resources to implement their projects. They enabled the encounter between entrepreneurs, on the one side, and multiple programs and actors, on the other side, which were heterogeneous in terms of supply content, intervention level (European, Federal, Regional-Länder, local), and status (public and private actors).

\subsection{The fragility of the local intermediation collective action initiated by BioRegio}

However, as shown by an analyis of the elements enabling the intermediation activity until 2001 , as well as by developments after 2001 , this intermediation activity - which is key to understanding the surge in new venture creations - was only slightly enhanced by the cluster policy studied.

\subsubsection{The role of contextual elements}

BioRegio did foster the capacity of newly created support organizations to act as intermediaries between entrepreneurs and resource providers through, first, the aforementioned creation of inter-knowledge and division of labor among organizations based 
in the regions supporting entrepreneurship and, second, through increased interactions between scientists and support organizations, which made the latter able to identify entrepreneurs in the early stages of their project needing resources and intermediation services. These increased interactions resulted mainly from the continuous organization of events - before and after BioRegio's results were announced - where support organizations presented their service proposals.

However, two contextual elements, independent from BioRegio, were important for this intermediation activity: the venture-capital context and the biotech industry life-cycle stage (therefore, the entrepreneurs' profiles). First, funding was greatly available at the time when BioRegio took place, in the form of venture-capital. Biotech firms are highly capital-intensive because implementing an $R \& D$ project up to the stage where an innovative product (e.g. a new active compound, drug, diagnostics system or research tool) can be commercialized takes several years and often requires millions of dollars. In Germany, the number of venturecapital firms investing in biotechnology surged from two at the beginning of the 1990's to over 15 by early 1999 (Mietsch, 1999) and 20 venture-capital firms initiating activity in biotechnology between 1995 and 2000 could be identified in this research. The amounts invested in life sciences ventures kept increasing in the late 1990's (see figure 2). This new type of funding was so widespread that many investors were actively seeking projects to invest in.

"In 1998, anyone wanting money for his company could get some. There was so much money everywhere... Venture-capitalists didn't really pay attention to what you said to them. Someone from [a Berlin-based venture-capital firm] came to see us and he only asked three questions (...). In two months, we had the money." (biotech firm 3, founder/CEO)

The great availability of financial support mainly resulted from elements disconnected from BioRegio, namely: (i) the drastic increase of high technology stock markets (Nasdaq, Neuer 
Market) in that period and (ii) the incentive-laden public program ("BTU") noted that promoted venture-capital.

Insert Figure 2 about here

The second contextual element was that the biotechnology industry was new in Germany when BioRegio was launched. Therefore, most entrepreneurs were scientists with no prior experience in firm creation or management ${ }^{12}$ and deprived of significant relevant social capital, increased the need for this intermediation activity. The research revealed that this type of entrepreneur overwhelmingly used existing support actors and tools to gain access to needed resources, as opposed to more experienced entrepreneurs who mostly relied on their interpersonal networks.

The developments taking place after 2001 confirm the role of these two contextual elements and demonstrate the fragility of the intermediation activity described.

\subsubsection{The weakening of a local intermediation collective action after 2001}

From 2001 as the BioRegio program officially came to an end, the supply in funding resources for entrepreneurs sharply decreased. The Federal Ministry of Economy, assessing that the venture-capital market had become mature, lowered its support to venture-capital at the same time. For example in January 2003, the Tbg stopped offering a risk-covering system for equity investors with its silent partnerships and increased its interest rates. More importantly, high tech stock markets crashed at the end of 2000, initiating a plunge that lasted

\footnotetext{
${ }^{12}$ In my sample, a large proportion of the entrepreneurs were young scientists. Non-tenured academic researchers amounted to $40 \%$ of the overall founders between 1996 and 2000 (35 out of 88) and were engaged in $58 \%$ of venture creations (14 out of 24).
} 
for several years ${ }^{13}$. Combined with the public scaling back, this financial crisis resulted in a severe contraction in venture-capital for entrepreneurs.

"My problem is to make money! You start working, you make ten investments ... then, you can't sell any of them, half of them go bankrupt. After that kind of experiences, you'd rather not invest again if the project you are evaluating is not 100\% sure. In 2002, we didn't make any new investment in biotech (...). As long as IPOs are impossible, we don't want to extend our portfolio." (venture-capital firm, Berlin, January 2003)

The overall biotechnology investments made by venture-capital companies in Germany declined from 565 million euros in 2000 to 216 million euros by 2003 . Thus, according to a survey on German biotechnology firms in 2004, the general need for capital amounted to more than 600 million euros (Ernst \& Young, 2005).

In addition to this drastic decrease in venture-capital, the entrepreneur's profile also evolved. Because of the reduced attractiveness of start-up creations for young scientists in this difficult funding context and the maturing of the industry (existing biotechnology firms increasingly "generated" individuals with technological projects who wanted to create their own company), many firm founders after 2001 possessed more relevant social capital and some prior experience in firm creation/management. A small majority of them (12 out of the 21 founders of biotech firms between 2001 and 2003 studied) had been employed in a biotechnology or life science research company before creating their own business.

In this new context, local support actors and tools were significantly weakened. Still acting as intermediaries but in a reduced manner, they contributed only slightly to a few new venture creations, and were largely unable to sustain the development of existing ones. In firms created both after and before 2001, the entrepreneurs who managed to obtain funding (from venture capitalists or pharmaceutical companies) after 2001 did not use local public support

\footnotetext{
${ }^{13}$ Between September 2000 and March 2001, the value of biotechnology firms' stocks on Neuer Markt was more than halved. The decrease lasted until 2004 (Ernst \& Young, 2004).
} 
actors but preexisting interpersonal relations (between their initial investor and other investors, or between themselves and client firms).

Insert Table 5 about here

\section{Discussion}

As a result of the empirical results, the following theoretical proposition can now be made.

A cluster policy can enhance the creation of new ventures through a three-step mechanism:

1. creating a convergence of individual interests, which will enable a collective action aiming at sustaining entrepreneurship in territories;

2. bringing regional actors to formalize their initial cooperation through a process of organizational creation / stabilization ;

3. reinforcing the capacity of these newly created institutions to act as intermediaries between entrepreneurs and both territory-based and non territory-based institutions (variable in each region), through (i) the creation of inter-knowledge and division of labor among local organizations supporting entrepreneurship, (ii) increased interactions between potential entrepreneurs and support organizations.

Because the particular design of the cluster policy studied made it possible, it can be argued that this three-step social mechanism is enabled by a specific role of the Federal state - as designer of the policy. First, the Federal state sets general objectives which are consistent with other research and innovation or local development policies being implemented at the same time. Second, its criteria for selecting model regions govern "at a distance" the genesis of cluster organization projects. They bring local actors to list their regional capacities (regarding entrepreneurship support and research), therefore their specific problems and lacking resources, to conceive adhoc solutions and to combine in these proposed solutions already existing programs and tools at the federal, state and municipal levels. Third, apart from these 
explicit demands, the Federal state leaves considerable freedom to local actors in the conceiving of their local project and in its implementation, which enhances creativity at the territory-level.

These results make it possible to strengthen the literature on cluster policies and clusters on the specific issue of entrepreneurship. Four main contributions are suggested.

First, the research presented here deconstructs the notion of (regional) institutions that lies at the core of regional innovation systems and institutionalist approaches by providing this concept with a rich empirical content and by reintroducing the actors' perspective. Based on a nuanced analytical description of the regional actors at the centre of interactions generating an entrepreneurial dynamic, this paper shows, contrary to the claims often made in these theoretical perspectives, that key regional institutions cannot be considered as a given or naturally inherent to regions. Their genesis is a "problem" worth being studied and, as evidenced by the analysis of the collective action induced by BioRegio, most of the key regional institutions are socially constructed. Their identity - because of its high territoryspecificity - has to be specified, as well as the rationale for their actions. Several types of regional institutions are instrumental in enhancing entrepreneurship. Four types shall be distinguised: (i) initiators of a regional collective action, (ii) new region-specific institutions created as a result of the cluster policy's implementation and acting as intermediaries together with other local organizations supporting entrepreneurs, (iii) stabilizers of these new institutions (local firms in Heidelberg, state governments and an industry association in Berlin-Brandenburg), (iv) local resource providers (Heidelberg Innovation, BioRegio association in Heidelberg, state ministries of economy and research, local venture-capitalfirms in Berlin-Brandenburg) ${ }^{14}$. These institutions are interdependent: their action at a time $t$

\footnotetext{
${ }^{14}$ As stated in the results section, many resource-providers for entrepreneurs are also located outside of their territory (e.g. Tbg, Federal ministries of research and economy).
} 
is made possible by the actions of the others at time $t-1$ or $t+1$. The data showed that these institutions are highly contingent on regional resources and dynamics.

One conclusion can be drawn from this analysis. As opposed to institutional analyses in which institutions appear very stable (e.g. Casper, 2000) and to regional innovation systems specialists who view the regional level as the appropriate one for enhancing innovation processes, this study highlights the fragility of institutions playing a key role in regional entrepreneurship and demonstrates the limitations of such a territory-based collective action aimed at supporting new venture creations. These institutions survive due to the repeated behaviors of actors who work in them: they stay vibrant because these actors engage in various actions to gain support from other institutions (regional governments, industrial firms), to play an efficient intermediation role between entrepreneurs and other institutions (mainly venture-capital firms) and to manage to cooperate with newly created support institutions. As a factor that has been often overlooked in previous contributions dedicated to cluster policies to explain the region-specificity of institutions that are key for innovation processes (Braczyk et al., 1998; Cooke et al., 1997), territories are unequal in their capacity to build solutions for the problems that they face. Limitations in regional resources and support (e.g. the inability to build a venture-capital fund in Berlin-Brandenburg, due to a moderate involvement of local banks and the presence of a single large pharmaceutical company) constitute a constraint for the action of regional institutions created to support entrepreneurship. Finally, as evidenced by the post 2001 difficulties, they are strongly dependent upon their institutional environments (e.g. other national policies, availability of venture-capital, entrepreneurs' individual experience). 
The second contribution to the literature on cluster policies refers to the problematic notion of trust as an explanatory factor for cooperation and communication among regional actors within clusters. For regional innovation systems specialists, a cooperative culture and a high level of interaction, based in trust among regional actors, are core elements of a functioning innovative cluster (Cooke et al., 1997; Cooke, 2001). The concept of trust is problematic in that it is often used as an explanatory factor without actually being explained, making the claim sometimes tautological: actors are said to cooperate because they trust each other, and since they cooperate, to trust each other, but the elements founding this trust remain unexplained. The successive waves of collective cooperation at the territory level which were depicted in the cases studied could be explained by shared or convergent interests among regional actors and actors' instrumental rationality (the desire to solve identified problems with conceived solutions) without having to draw on the notion of trust. A first moment of cooperation and communication between territory-based actors occurred in 1995-1996, and enabled converging interests of individual actors. This was because local institutions were "ready" from a cognitive and an organizational perspective to engage in such a cluster policy. This collective cooperation persisted, even when financial support from the Federal ministry was not provided as in the 'losing' region case, because the collective plans conceived in the application phase were implemented in both losing and winning regions. This undifferentiated implementation of plans, which was observed - but unexplained - in later public contests (Eickelpasch and Fritsch, 2005) $^{15}$, was explained in an instrumental rationality perspective by the emergence of problem solving opportunities for some regional actors. Finally, these initial waves of collective action were stabilized in organizations and tools supporting entrepreneurs, giving rise to another kind of collective action: an intermediation activity between the

\footnotetext{
$1540 \%$ of the regions that lost the InnoRegio program - which aimed at strengthening the economic competitiveness and innovation capability in the eastern part of Germany by fostering regional innovation networks - still implemented their knowledge production concepts. In case of the Exist program, 79\% of refused projects were nevertheless implemented (Eickelpasch and Fritsch, 2005).
} 
entrepreneurs and their resource-providers. That is, a division of the entrepreneurs' support labor in which, more than trust, a formalization activity was required, made the cooperation between various organizations and tools sustainable. These empirical results invite scholars not to resort too quickly to the notion of trust to explain cooperation and communication within clusters, as the concept of instrumental and normative rationality may prove just as sufficient.

Third, this research provides a better understanding of the causal relationships between the increase in interactions among regional actors induced by some cluster policies and new venture creations, which have been previously stated but not explained (Eickelpasch and Fritsch, 2005). The causal link is indirect: the increased interactions and cooperation in the BioRegio application phase did not directly lead to new venture creations. They did so indirectly through a stabilization of the initial cooperation in the form of new tools and organizations acting as intermediaries. This result invites us to think that, in addition to informal cooperations that lie at the core of the regional innovation systems literature, formalized cooperations (resulting from informal ones) play a key role in supporting regional entrepreneurial dynamics

The fourth major contribution of the paper is to expand multi-level governance explanations that underline the existence of several levels of action (national, regional, and municipal) involved in cluster policies (e.g. Sternberg et al., 2010). The cases studied empirically validates the hypothesis that cluster policies are "helpful by integrating previously separate fields of policy" (Sternberg et al., 2010, p. 1071) and provides insights into the modalities of this integration. In fact, these policies are helpful in that they create coordination, at a political-administrative level, between existing public programs. I show how previous or 
parallel municipal, regional and state policies for various purposes were combined by support actors in each territory after the launching of BioRegio. Cluster policies are also helpful for entrepreneurs in that they create coherence between public policies existing at various levels, therefore providing visibility and facilitating easier access to resources.

\section{Conclusion}

The analysis of the dynamic induced over 10 years by a cluster policy offers new insights into the role and nature of key regional institutions for new venture creations. Because of the exploratory nature of the results and the usual limitations regarding generalization, future research could investigate in a more systematic and comparative perspective, the effects of cluster policies on high-tech new venture creation and development across multiple countries. In particular, this research invites researchers to empirically study the effects of such policies on the performance of these new ventures, including their innovation ability, economic profitability, survival and development rates. Empirical results on these issues would provide further light on the doubts raised by several scholars on the capacity of public action, as opposed to market mechanisms, to create economically efficient and innovative clusters (Cooke, 2001; Dohse, 2007).

The study has several implications for public policies promoting high-tech entrepreneurship. First, at least some policies should pursue the objective of having territorial interconnected tools and organizations which support entrepreneurs, especially in the early stages of an industry when entrepreneurs are inexperienced. Second, this paper raises important questions concerning the time frame usually chosen by politicians or public administrations to specifically promote biotechnology advances and their commercialization. A five-year budget horizon seems too short to enhance entrepreneurial initiatives to permit newly created firms to sufficiently develop technologies that can be commercialized. Third, the paper shows that the 
sense of "right moment" can be crucial for the success of any public policy endeavour. BioRegio echoed other national, regional and municipal policies launched in the same period as well as a growing interest by the financial community in biotechnology. Thus, the program results can also be explained by its timing.

Fourth, the current study questions the efficacy of such a cluster policy. By drastically enhancing the number of new venture creations by inexperienced entrepreneurs-scientists and by amplifying the effects of the high-tech financial bubble of the late 1990's, BioRegio favored the creation of small and fragile start-ups, with sometimes unclear market perspectives and, therefore, risky chances of survival and profitability. A more selective policy targeted at sustaining the most promising ventures and entrepreneurs, without the 'artificial' geographical limits imposed by such cluster policies, could have been more relevant for enhancing entrepreneurship in a sustainable way. 


\section{Appendix}

Figure 1: Evolution of number of biotech firms in Germany (1995-2004)

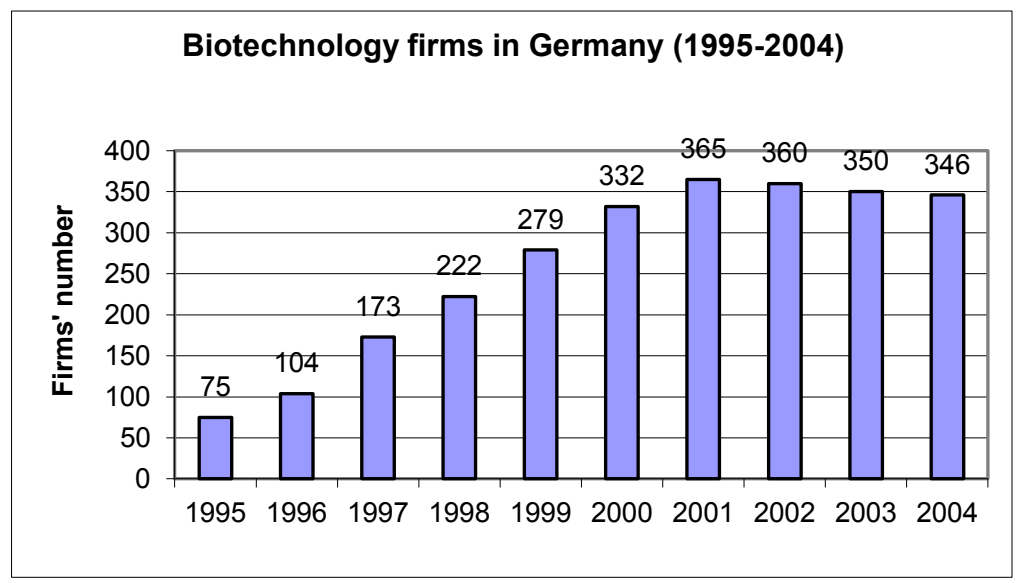

Source: Ernst \& Young, 2002, 2004, 2005.

Figure 2: Biotechnology investments made by VC companies based in Germany (1996 - 2001)

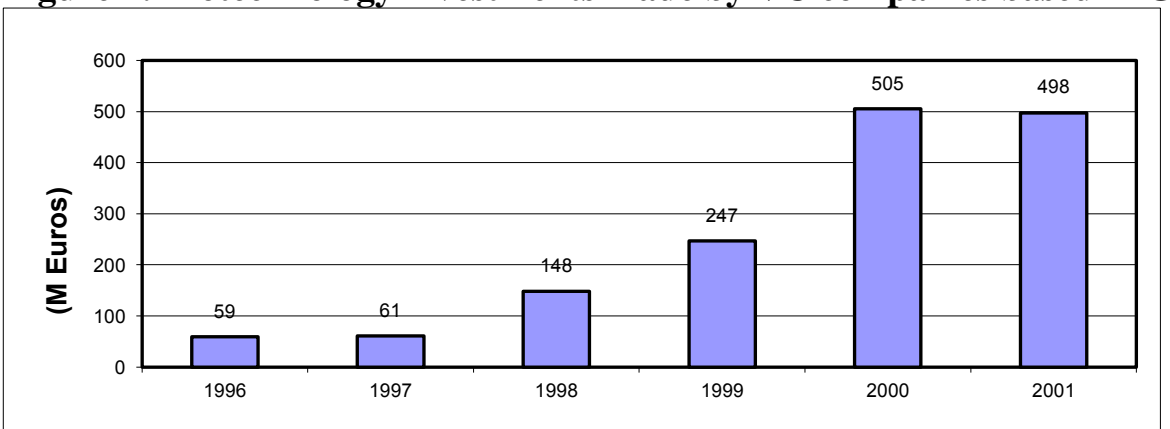

Sources: European Private Equity and Venture Capital Association (EVCA); Center for European Research in Economics (ZEW).

Table 1: Decision process to participate in BioRegio

\begin{tabular}{|c|c|c|c|}
\hline Region & Time & Initiator & Reason for wanting to participate \\
\hline $\begin{array}{l}\text { Rhine-Neckar } \\
\text { Triangle }\end{array}$ & $\begin{array}{l}\text { Immediately } \\
\text { after } \\
\text { October } \\
1995\end{array}$ & $\begin{array}{l}\text { Dean of Heidelberg University: } \\
\text { invited most potentially } \\
\text { concerned institutions (research } \\
\text { institutions, pharmaceutical and } \\
\text { chemical firms) to meet for an } \\
\text { initial collective reflection }\end{array}$ & $\begin{array}{l}\text { Strategic and normative reasons: a } \\
\text { will to differentiate Heidelberg } \\
\text { university from competitors through } \\
\text { an engagement in life sciences, a } \\
\text { desire to create new professional } \\
\text { opportunities for students and to } \\
\text { gain additional revenues through } \\
\text { cooperations with firms, and a belief } \\
\text { in the university's mission of } \\
\text { commercializing academic } \\
\text { knowledge }\end{array}$ \\
\hline $\begin{array}{l}\text { Berlin- } \\
\text { Brandenbrug }\end{array}$ & $\begin{array}{l}\text { In the } \\
\text { months } \\
\text { prior } \\
\text { October } \\
1995\end{array}$ & $\begin{array}{l}\text { Political-administrative actors, } \\
\text { mainly (i) cabinet director } \\
\text { [Staatssekretär] in charge of } \\
\text { urban development and } \\
\text { technology of the Berlin state }\end{array}$ & $\begin{array}{l}\text { State ministry had already identified } \\
\text { the biotechnology sector as a key } \\
\text { industry to be supported for local } \\
\text { economic development purposes, } \\
\text { both actors saw BioRegio as an }\end{array}$ \\
\hline
\end{tabular}




\begin{tabular}{|l|l|l|l|}
\hline & $\begin{array}{l}\text { ministry of economy, (ii) an } \\
\text { organization ("TSB") created and } \\
\text { supported by this state ministry } \\
\text { with the mission to identify key } \\
\text { technological areas for Berlin and } \\
\text { to promote academia-industry } \\
\text { cooperation }\end{array}$ & \\
\hline
\end{tabular}

Table 2: $\quad$ Local actors' reasons for wanting to participate in BioRegio

\begin{tabular}{|l|l|}
\hline \multicolumn{1}{|c|}{ Local actors } & \multicolumn{1}{c|}{ Reasons } \\
\hline Directors of research institutes & $\begin{array}{l}\text { Viewed BioRegio as an opportunity to make } \\
\text { researchers more aware of the need for applied } \\
\text { science and economic transformation of academic } \\
\text { results, to create more scientific jobs, and to } \\
\text { obtain external funding }\end{array}$ \\
\hline Biotech firms & $\begin{array}{l}\text { Expected the public contest would generate a } \\
\text { number of R\&D grants and an improvement of } \\
\text { their environments including greater public } \\
\text { acceptance and more liberal regulations }\end{array}$ \\
\hline Representatives from local public authorities & $\begin{array}{l}\text { Hoped to promote economic growth in their } \\
\text { territories or regions }\end{array}$ \\
\hline Pharmaceutical firms & $\begin{array}{l}\text { Mainly motivated by a desire to sustain their } \\
\text { territory's general economic dynamics }\end{array}$ \\
\hline
\end{tabular}

Table 3: Three types of tools and organizations supporting entrepreneurs in the late 1990's

\begin{tabular}{|c|c|c|}
\hline Type & Purpose & Example \\
\hline $\begin{array}{l}\text { Technology transfer } \\
\text { offices ("TTOs") }\end{array}$ & $\begin{array}{l}\text { To foster the licensing } \\
\text { of patents and venture } \\
\text { creations by scientists }\end{array}$ & $\begin{array}{l}\text { In Heidelberg: University of Heidelberg, German } \\
\text { Cancer Research Center and European Molecular } \\
\text { Biology Laboratory TTOs }\end{array}$ \\
\hline $\begin{array}{l}\text { Specialized } \\
\text { "technology parks" }\end{array}$ & $\begin{array}{l}\text { To promote national } \\
\text { technological } \\
\text { innovation (for fed. } \\
\text { govt); to seek new } \\
\text { financial resources } \\
\text { (for universities) }\end{array}$ & $\begin{array}{l}\text { In Berlin-Brandenburg: Biotechnology Center in } \\
\text { Henningsdorf (public initiative); Biotech Park } \\
\text { Charlottenburg (private initiative) }\end{array}$ \\
\hline $\begin{array}{l}\text { Other systems } \\
\text { sustaining } \\
\text { technological } \\
\text { innovation and new } \\
\text { firm creations }\end{array}$ & $\begin{array}{l}\text { To foster a region's } \\
\text { economic } \\
\text { development and } \\
\text { technological } \\
\text { competitiveness }\end{array}$ & $\begin{array}{l}\text { (i) direct financial subsidies for R\&D projects } \\
\text { undertaken by firms or for young innovative } \\
\text { companies (e.g. Land Venture-Capital Funds } \\
\text { and the Bade-Württemberg Venture Capital } \\
\text { Funds); } \\
\text { (ii) free counseling ("coaching") services offered } \\
\text { to entrepreneurs; } \\
\text { (iii) business plan contests ; } \\
\text { (iv) Land-specific tools designed to help scientists } \\
\text { create their companies (e.g. "Junge } \\
\text { Innovatoren" launched in Baden-Württemberg } \\
\text { in 1995) }\end{array}$ \\
\hline
\end{tabular}

\footnotetext{
${ }^{16}$ Source : (Krücken, 1999, 2003)
} 
Table 4: $\quad$ Main contact-making by support organizations between entrepreneurs and funding actors

\begin{tabular}{|l|l|}
\hline \multicolumn{1}{|c|}{ Region } & \multicolumn{1}{c|}{ Main contacts made with funding actors } \\
\hline Rhine-Neckar & $-\quad$ "Heidelberg Innovation" seed funds + Federal "Tbg" (co-financing \\
& with VC) \\
& $-\quad$ BioRegio Association (R\&D grant) \\
\hline Berlin-Brandenbrug & $-\quad$ Regional states, Federal ministries of research and economy, \\
& $\begin{array}{l}\text { European Union (direct subsidies) } \\
-\end{array}$ \\
& "Tocal VC firms" \\
\hline
\end{tabular}

Table 5: $\quad$ Findings describing the dynamic initiated by BioRegio in two regions

\begin{tabular}{|c|c|c|}
\hline \multirow[b]{2}{*}{ 1995-1996 } & & \\
\hline & $\begin{array}{l}\text { Genesis of a territory-based collectiv } \\
\text { Involvement of public and pr } \\
-\quad \text { Inventory of regional c } \\
\text { - Conceiving of a local project (ex } \\
\text { BioRegio Association } \\
\text { Seed Funds \& managing company } \\
\text { ("Heidelberg Innovation") (funded } \\
\text { by BASF, Roche Diagnostics, Knoll, } \\
\text { Merck \& local banks, saving banks, } \\
\text { insurance companies) }\end{array}$ & $\begin{array}{l}\text { ction to support entrepreneurs } \\
\text { te actors in territories: } \\
\text { bilities in biotechnology } \\
\text { ng and new organizations \& tools): } \\
\text { - BioTop (supported by regional } \\
\text { states Berlin and Brandenburg) } \\
\text { - Tools by technology parks } \\
\text { (Biostart,...) }\end{array}$ \\
\hline \multirow[t]{3}{*}{$\begin{array}{l}\text { Nov. 1996- } \\
2001\end{array}$} & \multicolumn{2}{|c|}{$\begin{array}{l}\text { Formalization of the initial cooperation by an organizational creation/stabilization } \\
\text { - Genesis of new local support organizations and tools (Nov. 1996-1997) } \\
\text { - Stabilization of BioRegio-derived organizations (1998-2001) : } \\
\text { Support organizations created with BioRegio becoming viable: } \\
\text { - funding from Federal research ministry, } \\
\text { region-based industry \& banks }\end{array}$} \\
\hline & \multicolumn{2}{|c|}{$\begin{array}{l}\text { Context: Emergence of new support tools \& organizations for entrepreneurs in the frame } \\
\text { of regional and municipal policies }\end{array}$} \\
\hline & \multicolumn{2}{|c|}{$\begin{array}{l}\text { Intermediation role of local support actors and tools between entrepreneurs \& their } \\
\text { partners: } \\
\quad-\quad \text { norm diffusion } \\
-\quad \text { counseling } \\
\text { - contact-making with (i) scientific partners, (ii) other support actors, } \\
\quad \text { (iii) funding actors } \\
\text { Local support organizations and tools catalyzed entrepreneurial projects \& enabled the } \\
\text { encounter between entrepreneurs and multiple programs/actors }\end{array}$} \\
\hline 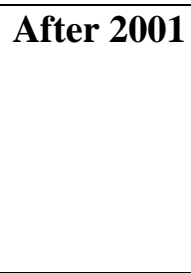 & \multicolumn{2}{|c|}{$\begin{array}{l}\text { Weakening of a local intermediation collective action } \\
\text { Decrease of funding supply for entrepreneurs } \\
\& \\
\text { More experienced entrepreneurs with richer social capital } \\
\Downarrow \\
\text { ited capacity of action for local support organizations and tools }\end{array}$} \\
\hline
\end{tabular}


Table 6 : Interviews carried out by actors' categories

\begin{tabular}{|c|c|c|c|c|c|}
\hline & No. of organizations & $\begin{array}{l}\text { Rhine-Neckar } \\
\text { Triangle }\end{array}$ & \begin{tabular}{|l|} 
Berlin- \\
Brandenb \\
urg \\
\end{tabular} & Other & $\begin{array}{l}\text { No. of } \\
\text { intervie } \\
\text { ws }\end{array}$ \\
\hline $\begin{array}{l}\text { Biotech firms (founders } \\
\text { and CEOs) }\end{array}$ & 42 & 21 & 20 & 1 & 67 \\
\hline Pharmaceutical firms & 6 & 2 & 3 & 1 & 7 \\
\hline State \& Federal ministries & 5 & - & 3 & 2 & 10 \\
\hline $\begin{array}{l}\text { Local public support } \\
\text { actors* }\end{array}$ & 16 & 6 & 7 & 3 & 34 \\
\hline $\begin{array}{l}\text { Universities/ research } \\
\text { centers** }\end{array}$ & 3 & 1 & 2 & - & 3 \\
\hline Financing institutions & $\begin{array}{r}24 \\
\text { (includ. VC firms and } \\
\text { Tbg/KfW: } 22 \text { ) }\end{array}$ & 1 & 10 & 13 & 32 \\
\hline Consultants / auditors & 8 & 1 & 1 & 6 & 8 \\
\hline TOTAL & 103 & 34 & 45 & 24 & $161 * * *$ \\
\hline
\end{tabular}

* Biotechnology promotion associations, local seed funds, technology parks, technology transfer offices. ** other than technology transfer offices.

*** The difference between this figure and the total number of interviews that were actually carried out $(\mathrm{n}=$ 157) results from the fact that some interviews were conducted with individuals who belonged to two organizations in the study. However, the number of such individuals was small.

The questions asked during the interviews aimed at reconstructing the historical local and national dynamics that took place in Germany especially in the booming phase of the biotechnology industry (from the mid 1990's on). The questions asked to entrepreneurs were also intended to illuminate, chronologically, how they created and developed their ventures.

Table 7: $\quad$ Biotechnology firm cases studied

\begin{tabular}{|c|c|c|c|c|c|}
\hline Creation date & 1980-1995 & 1996-1998 & 1999-2000 & $2001-2003$ & Total \\
\hline $\begin{array}{r}\text { In-depth longitudinal studies } \\
\text { Rhine-Neckar Triangle } \\
\text { Berlin-Brandenburg }\end{array}$ & $\begin{array}{l}5 \\
2\end{array}$ & $\begin{array}{l}2 \\
2\end{array}$ & $\begin{array}{l}4 \\
4\end{array}$ & 3 & $\begin{array}{l}12 \\
10\end{array}$ \\
\hline $\begin{array}{r}\text { Total cases } \\
\qquad \begin{array}{r}\text { Rhine-Neckar Triangle } \\
\text { Berlin-Brandenburg }\end{array}\end{array}$ & 10 & $\begin{array}{l}5 \\
3\end{array}$ & $\begin{array}{r}7 \\
10\end{array}$ & 6 & $\begin{array}{l}21 \\
20\end{array}$ \\
\hline
\end{tabular}




\section{References}

Audretsch D, Stephan P, 1996, "Company scientist locational links: the case of biotechnology" American Economic Review 86(3) 641-652

BMBF, 1996a "Delphi-Bericht 1995 zur Entwicklung von Wissenschaft und Technik - Mini Delphi" (Bundesministerium für Bildung, Wissenschaft, Forschung und Technologie, Bonn)

BMBF, 1996b "Bundesbericht Forschung 1996" (Bundesministerium für Bildung, Wissenschaft, Forschung und Technologie, Bonn)

Borràs S, Tsagdis D, 2008 Cluster Policies in Europe, Firms, Institutions, and Governance (Edward Elgar, Cheltenham)

Braczyk H-J, Cooke P, Heidenreich M, 1998 Regional Innovation System: The Role of Governance in a Globalized World (UCL Press, London)

Burfitt A, McNeill S, Gibney J, 2007, "The dilemmas of operationalizing cluster policy: the Medical technology cluster in the West Midlands" European Planning Studies 15 1273-1290

Casper S, 2000, "Institutional Adaptiveness, Technology Policy, and the Diffusion of New Business Models: The Case of German Biotechnology" Organization Studies 21(5) 887-914

Casper S, 2007, "How do technology clusters emerge and become sustainable ? Social network formation and inter-firm mobility within the San Diego biotechnology cluster" Research Policy 36 438-455

Cooke P, 1998, "Introduction: origins of the concept", in Regional Innovation Systems Eds HJ Braczyk, P Cooke, M Heidenreich (UCL Press, London)

Cooke P, 2001, "Regional Innovation Systems, Clusters, and the Knowledge Economy" Industrial and Corporate Change 10 945-975

Cooke P, Gomez Uranga M, Etxebarria G, 1997, "Regional innovation systems: Institutional and organisational dimensions" Research Policy 26 475-491

Development Bank of Japan, 2006 "Erfolgreiche Biotechnologieregionen in Deutschland. Die Beispiele Berlin-Brandenburg, München, Rhein-Neckar-Dreieck", Repräsentanz Frankfurt am Main Research, Mainzer Landstrasse 46, 60325 Frankfurt am Main

Dohse D, 2000a, "Regionen als Innovationsmotoren: Zur Neuorientierung in der deutschen Technologiepolitik", in Kieler Diskussionsbeiträge, August 2000, Institut für Wirtschaft Kiel, Kiel

Dohse D, 2000b, "Technology policy and the regions - the case of the BioRegio contest" Research Policy 29 1111-1133

Dohse D, 2007, "Cluster-Based Technology Policy-The German Experience" Industry and Innovation 14 69-94

Doloreux D, Bitard P, 2005, "Les systèmes régionaux d'innovation : discussion critique" Géographie, Economie, Société 7 21-36

Duranton G, Martin P, Mayer T, Mayneris F, 2009 Whither clusters? Lessons from the French experience (Oxford University Press) 
Eickelpasch A, Fritsch M, 2005, "Contests for cooperation - A new approach in German innovation policy" Research Policy 34 1269-1282

Eisenhardt K M, 1989, "Building theories from case studies research" Academy of Management Review 14 535-550

Eisenhardt K M, Graebner M E, 2007, "Theory building from cases: opportunities and challenges" Academy of Management Journal 50(1) 25-32

Ernst\&Young, 2002, "Neue Chancen. Deutscher Biotechnologie-Report 2002", Ernst \& Young GmbH, Theodor-Heuss-Anlage 2, 68165 Mannheim

Ernst\&Young, 2004, "Per Aspera Ad Astra. "Der steinige Weg zu den Sternen". Deutscher Biotechnologie-Report 2004", Ernst \& Young GmbH, Theodor-Heuss-Anlage 2, 68165 Mannheim

Ernst\&Young, 2005, "Kräfte der Evolution. Der Deutsche Biotechnologie-Report 2005", Ernst \& Young GmbH, Theodor-Heuss-Anlage 2, 68165 Mannheim

Ernst \& Young, 2008, "Auf gutem Kurs. Deutscher Biotechnologie-Report 2008", Ernst \& Young GmbH, Theodor-Heuss-Anlage 2, 68165 Mannheim

Feldman M, 2003, "The Locational Dynamics of the US Biotech Industry: Knowledge Externalities And The Anchor Hypothesis" Industry and Innovation 10 311-328

Feldman M, Francis J, Bercovitz J, 2005, "Creating a Cluster While Building a Firm: Entrepreneurs and the Formation of Industrial Clusters" Regional Studies 39 129-141

Grossetti M, Barthe J-F, 2008, "Dynamique des réseaux interpersonnels et des organisations dans les créations d'entreprises" Revue française de sociologie 49 585-612

Hall P, Soskice D, 2001 Varieties of Capitalism: The Institutional Foundations of Comparative Advantage (Oxford University Press, Oxford)

Ireland D R, Reutzel C R, Webb J W, 2005, "Entrepreneurship Research in AMJ: What Has Been Published, and What Might the Future Hold?" Academy of Management Journal 48 556-564

Krauss G, Stahlecker T, 2001, "New Biotechnology Firms in Germany: Heidelberg and The BioRegion Rhine-Neckar Triangle" Small Business Economics 17 143-153

Krücken G, 1999 Jenseits von Einsamkeit und Freiheit: Institutioneller Wandel von Universitäten. Eine Untersuchung zum Wissens- und Technologietransfer an den Universitäten des Landes Nordrhein-Westfalen (Universität Bielefeld, Fakultät für Soziologie)

Krücken G, 2003, "Learning the 'New, New Thing': On the role of path dependency in university structures" Higher Education 46 315-339

Langley A, Royer I, 2006, "Perspectives on Doing Case Study Research in Organizations" M@n@gement981-94

Maurer I, Ebers M, 2006, "Dynamics of Social Capital and their Performance Implications: Lessons from Biotech Start-ups" Administrative Science Quarterly 51 262-292

Mietsch A, 1999 Bio-Technologie. Das Jahr-und Adressbuch 1999 (Biocom, Berlin)

OECD, 1999 Boosting Innovation. The Cluster Approach (OECD Publishing) 
Porter M E, 1998, "Clusters and the New Economics of Competition" Harvard Business Review 76(6) 77-90

Powell W, Packalen K, Whittington K, 2011, "Organizational and Institutional Genesis: The Emergence of High-Tech Clusters in the Life Sciences", in The Emergence of Organizations and Markets Eds J Padgett, W Powell

Proudfoot N, 2004, "The Biopharmaceutical Cluster in Oxford", in Changing Governance of Local Economies: Responses of European Local Production Systems Eds C Crouch, P Le Galès, C Trigilia, H Voelzkow (Oxford University Press, Oxford, New York) pp 237-260

Saxenian A, 1994 Regional Advantage: Culture and Competition in Silicon Valley and Route 128 (Harvard University Press, Cambridge, MA)

Schumpeter J A, 1934 The Theory of Economic Development (Harvard University Press, Cambridge, MA)

Staehler T, Dohse D, Cooke P, 2007, "Evaluation der Fördermassnahmen BioRegio und BioProfile", Report commisioned by BMBF (Bundesministerium für Bildung und Forschung), Consulting für Innovations- und Regionalanalysen, Institut für Weltwirtschaft and der Universität Kiel, Centre for Advanced Studies in the Social Sciences

Sternberg R, Kiese M, Stockinger D, 2010, "Cluster policies in the US and Germany: varieties of capitalism perspective on two high-tech states" Environment and Planning $C$ : Governement and Policy 28 1063-1082

Yin R K, 1994 Case study research: design and methods - 2nd ed. (Sage Publications, Thousand Oaks, California)

Zucker L, Darby M, Brewer M, 1998, "Intellectual Capital and the Birth of U.S. Biotechnology Enterprises" American Economic Review 88 290-306 